an after-finishing for sale.-Rude as they are, and this is one of the points we dwell upon in proof of their antiquity, they were used in the state in which we find them, for otherwise we should find the finished examples elsewhere, which as yet, at any rate, we have done nowhere. We find stone and flint celts, polished and ground; but those, as we long enough ago observed in this journal, were used by the broad flat end. The large fossil lint-implements were all worked to a point, and which point, contrary to anything we know of the use of any other stone tool, ancient or modern, was the part used. There is thus, besides the absence of chipping, one positive character at least which separates the fossil implements entirely from any other effort of savage industry. Will M. Gras assert he has ever seen a pointed weapon either ground or polished?

M. Gras further lays great stress on M. Gaudry having found nine worked flints on the same level. We might speak of levels in regularly stratified deposits, what levels are there in a gravel-bed?

Taking it for granted, however, nine were found on one level, is that number so large as to cause surprise? If-why may we not indulge in conjunctions?-if there were a fishing-station on the spot, would nine be a large number to be presumed to be lost during the sojourn of the fishermen there? Or is there not an infinity of incidents which might bring together so trifling a lot?

Finally, to close our comments, may we not justly ask M. Gras if the flint implements belong to historic times? Who were the men that used them?*

\title{
NOTES ON THE GEOLOGY OF MAIDSTONE.
}

By W. H. Bensted, Esq.

The outcroppings of the Cretaceous strata in the valley of the Medway, the great quarries in the lower beds of the greensand for the much-used Kentish ragstone, the extensive chalk-pits at Burbam and other places, the pottery clay-pits and the numerous brickfields, afford excellent facilities for the observation of the geological structure of Maidstone and the surrounding country.

By taking the road from Rochester, through Maidstone, to Linton, the outerops of the Chalk and its subordinate beds are passed over in succession across their line of strike.

* The letters from Mr. Peacock, Mr. Evans, and Mr. Blake, in last week's 'Parthenon,' which has been published since our remarks were in type, show that we have by no means exhausted, even in our extended article, the refutations which cau be given to M. Gras' opinions. 

The chalk hills, are covered, at various places, with a red, tenacious (Post-Tertiary or Diluvial) clay, in which great quantities of flint nodules are buried.

At the "Upper Bell," on the Rochester road, the chalk hill is 620 feet above sea-level, and from this altitude the spectator's view ranges over a great extent of beautiful country. In the left bank, a large tabular bed of flint, about two inches thick, crops out. Layers of hard chalk also occur here, containing numerous sharp casts of fossils-Trochi, Dentalia, Hamites, Scaphites, small Ammonites, etc. This bed is also met with at Boxley and Deptford. It is known to but few collectors, and some perseverance in breaking up pieces of this hard chalk is necessary to obtain specimens of its fossils.*

In a field at Boxley Hill, I found an Echinus in a lump of the chalk which had been strewed over the land, in the interior of which were minute shells, apparently of a species of Arca (?), that had probably gained access to the empty dead shell, as the Echinidr do not swallow entire shells, but gnaw dead fishes and such-like objects with their teeth. The Spatangidæ live by swallowing sand and mud, deriving their nutriment from the organic particles they contain. Near here the Lower Chalk makes its appearance, and the great Burham pits, from which Mr. Toulmin Smith obtained many of his beautiful specimens of Ventriculites, are about a mile off, in a westerly direction. These pits are famous for the very numerous fossils of high interest which they have produced. At Halling, too, on the opposite side of the Medway, considerable quantities of chalk are dug for burning; the lime made from the chalk of these places being considered of very superior quality. It is known commercial lyas "greystone lime."

In $1839 \mathrm{I}$ discovered the femur of a turtle in a pit at Halling, and also an abdominal plate at Burham. These were the first remains of turtles discovered in the Kentish chalk. But a few years later I had the good. fortune to find a most perfect specimen. This unique fossil I presented to Dr. Mantell, and it is now in the British Museum.

It was figured and described by him in the 'Pbilosophical Transactions,' pl. 2, for 1841, and sub-

* This scems to be the bed of "chalk-rock" referred to by Mr. Whitaker iu the Quart. Journ. Geol. Soc. vol. xvii. p. 170. -Ed, GEOL.

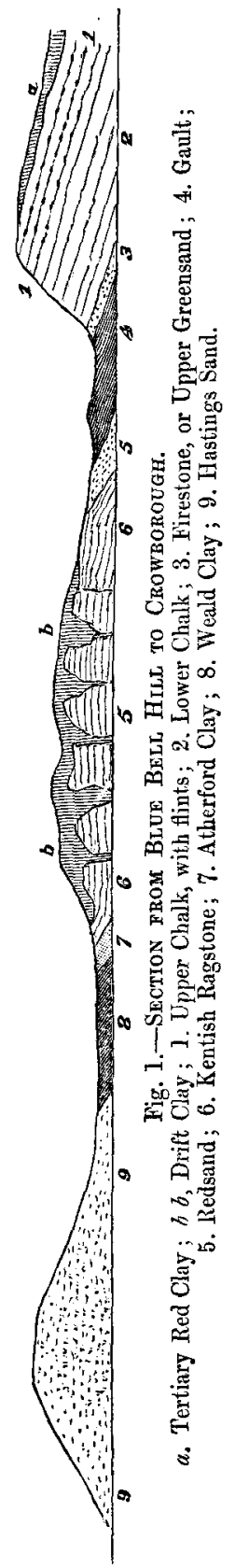


sequently by Professor Owen, in the volume of the Palæontographical Society's publications for 1851 .

The chalk was dissected away, so as to admit of the removal of a
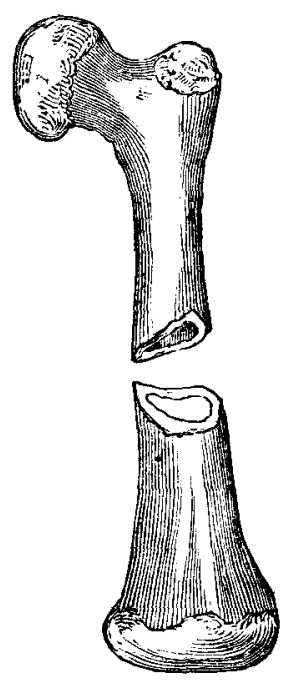

Fig.2.-Femur of Trionyx from Halling Chalk Pit. great portion of the dorsal shell, and thus some of the vertebræ, four plates of the plastron, and a coracoid bone were brought to view.

Since the discovery of the Chelonia Benstedii, Mrs. Smith, of Tunbridge Wells, has procured from the same pit a series of marginal and sternal plates of a turtle of very large size. These specimens have been admirably cleared from the chalk, and now form a part of her most interesting and valuable collection.

In 1847, another fossil turtle was found in an adjoining pit in the Lower Chalk. It corresponded in size and number of plates with, indeed it was almost a facsimile of, the original Chelonia Benstedii.

Perhaps the most interesting fossils found in this locality, were some long, slender, cylindrical bones, which Professor Owen considered, in the first instance (1840), if they were the remains of a bird at all, as being more allied to the Albatross than to any other. The bones there noticed are the portion of a humerus nine inches long, with one extremity nearly entire, but the other broken completely off. The uncertainty expressed by Professor Owen was afterwards cleared up by the discovery, by Dr. Bowerbank, of the head and teeth of a new species of Pterodactyle, described by him in the Geological Society's Journal, 1845, when he assigned these bones, from their microscopic structure, to that extraordinary class of flying reptiles.

The fine specimen of Dolichosaurus, described in the Palæontological Society's Volume for 1851, was discovered here by Mrs. Smith, of Tunbridge Wells, in 1830. A similar fossil (probably part even of the same specimen) was obtained from this same locality by Sir Philip Egerton, in 1840, and was briefly described by Professor Owen as the remains of a lizard, consisting of a series of small vertebræ in their natural position. The vertebræ are united by ball-andsocket joints, and they are proved to belong to the Saurian class of reptiles by the presence of many long slender ribs, and by the conversion of two vertebræ into a sacrum. Portions of an ischium and a pubes are connected with the left side of the sacrum, and demonstrate that the reptile had hinder extremities. These typical parts are referred to particularly, as the specimen otherwise has certainly more the appearance of a serpent than a lizard. Serpents have long, slender ribs, and therefore the saurian character depends alone on the assumed sacrum, as the extremities are wanting.

In December, 1842, Professor Owen described a fossil paddle which 
was exhibited at the Geological Society's meeting, as that of a marine saurian, the phalangial digits not being articulated by convex and concave surfaces, as in the terrestrial group, but by plane faces. These were roughened, indicating ligamentous connection.

Professor Owen then mentioned also the occurrence of vertebræ of a large Plesiosaurus in this chalk; the late Mr. Dixon, of Worthing, having had three or four in juxtaposition, which are now in the British Museum. He considered the specimen belonging to Mrs. Smith, of 'Tunbridge Wells, as probably referable to that geuus. It also presented considerable resemblance to another extinct genus, the Pliosaurus, but the bones were thicker and not so expanded at their extremities. There was also another large saurian of the Cretaceous epoch, the Mosasaurus; but although fine remains of its teeth and jaws had been discovered nany years ago, no extremities had ever been found. If the teeth of the Mosasaurus should be found in the locality where Mrs. Smith's specimen was got, he thought it might indicate that the paddle above referred to belonged to that genus.

The Firestone is very little developed in this neighbourhood. Tho only traces I have seen are thin beds, a few inches only in thickness, at Snodland, near the church. Between there and Burham Church, a bar of rock runs across the river; it is never dry, and its obstruction causes a considerable fall when the tide is low.

The best section of the Gault is at a place called the Varnes, on the banks of the Medway, near New Hythe. At low-water the lowest beds are to be seen. The bank is about fifty feet above low-water. Slips are frequently occurring from the effects of the weather, and the current of the river washing away the softer parts, when fossils may be found in abundance. Thence the gault may be traced to Folkestone on the one side, and into Sussex on the other, forming a valley at the foot of the chalk-downs. Its usual colour is light blue when dry, but of a very dark blue when wet. Some veins of red ochreous clay marked with Fuci ( $F$. Targonii) occur frequently.

The gault forms a stiff soil, locally known as "black land," and its outcrop generally appears as a marshy tract. From its tenacity and its dipping under the chalk-strata, through the cracks and fissures of which the water finds its way, it forms a subterranean reservoir from the junction or lip of which the springs burst out.

I would here say a few words on the spring-heads of the Maidstone, district. These are nearly all situated in circular cavities in the Lower Chalk, where it projects over the Gault, and an interesting phenomenon is observable in the retrogression of the spring-head into the chalk by its erosive action. If we suppose the waters originally burst out at the foot of the hill $B$, fragments of chalk would be carried away at that point, and as the sides grew higher the rim of vol. $v$.

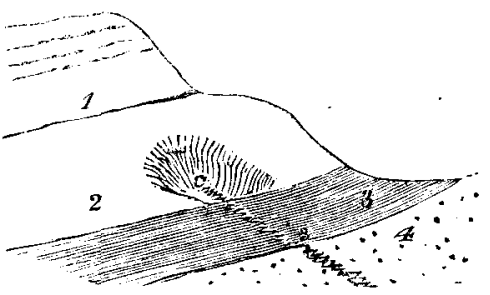

Fig. 3.-Spring-head. 
the hole would expand upon the surface, and thus a rounded cavity would be formed, at the bottom of which the spring is now seen to issue (at A).

The water of these chalk springs is highly charged with calcareous matter, obtained in flowing through the chalk fissures, and this is precipitated on the fragments of sticks, roots, and leaves, which fall into the streams. At Boxley Abbcy very fine specimens of calcareous tufa may be procured, as may be also incrustations of fir-cones, etc., by placing them in the water near the spring-head.

A spring of water at Cosington, bursting from the Lower Chalk, deposits a coating upon the stones in its course of a bright crimson, which at one time was considered to proceed from an impregnation of iron-pyrites, but has now been determined to be of vegetable origin.

The fossils of the Gault most common are Ammonites, Hamites, and Inocerami, At the Varnes great quantities of round nodular masses are found. On breaking these stones a nucleus with concentric waving lines is seen; they take a polish without difficulty. These nodules, so rich in phosphate of lime, have been conjectured to be coprolitic, but my opinion has long been that they are originally of zoophytic or spongeous origin, and that the presence of the phosphate is attributable to deposition from the water of the Cretaceous sea, as portions of ammonites and inocerami are found to contain equally considerable quantities of phosphate.

We now come to the Lower Greensand.-The White or Bearsted sand lies immediately under the Gault, upon the red ferruginous sands. It is limited in extent, occurring only at certain places and in different states of purity, White Heath, near Hollingbourne, affording a very superior kind. I never heard of any fossils being found in it.

The next deposit is the ferruginous sand, with layers of ironstone. These beds rise rather abruptly from beneath the Gault at Box-

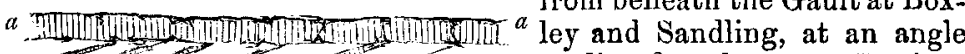

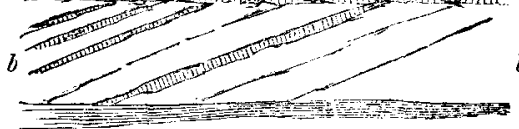

Fig. 4. - $a a$, horizontal layer of ferruginous sandstone; $b b$, etc., layers in a false stratification. casts of zoophytes or sponges, generally of a cylindrical shape. Some appear allied to Siphonia, having a bulbous head, the sand being loose or non-segregated in the interior. A few marine shells may be detected by close inspection, chiefly Terebratulæ. Trigonia alaformis occurs in a bank of this sand near Thornhills. In Sandling Wood about twenty feet of the sand is exposed, in which the ramification of a marine plant is seen to great advantage. In places rings of ironstone, circular and oblong, give an appearance of wavy lines, but by a little examination it may be seen that these lines are sections 
of bundles of tubes growing together; this is proved at another part by the exposure of longitudinal portions of the tubes running together nearly horizontally for a distance of four or five feet. By a turn of the bank the ends may be seen, presenting the connections of each pipe at the side.

In some situations at Bearsted a fine clean white and nearly pure silicious sand is found, occupying a division of the red sand adjoining the gault. The white beds are sometimes not seen near the surface, but appear to be below the red sand. Veins of red sand cross the beds of white sand in various ways.

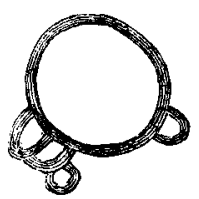

Fig. 5.-Trans. verse section of ironstone pipes.

The great development of the Kentish ragstone in the Maidstone district is a most important feature. It is found at various depths from the surface, and in detached beds of different magnitudes; the first in descending order rising from under the red ferruginous sands just mentioned. The beds then become broken and separated by valleys and faults; the latter filled up with gravel, red sand, rolled masses of yellow "fullers' earth," and red clay (brick-earth). The masses of stone extend across to the escarpment of the lower beds above the valley of the Wealden-a distance from Sandling to Linton of about five miles.

The ragstone at Barming Heath Hill has a thickness of eighty feet, and the whole series is passed through by a well sunk near the Lunatic Asylum.

The valley of the Medway is bounded on each side by this ragstone from Mill Hall to within a mile of Yalding, where the escarpment is separated by the opening in which the drainage-waters of the Weald flow out. Besides this great valley, which runs transversely to the escarpment, there are two others which separate it laterally, each giving rise to springs which fall into the Medway. A third vale or gorge has its course between the Loose Vale and the Medway. It runs from near the edge of the escarpment over the Wealden beds at Coxheath, in nearly a direct line to Tovil. This crack has very steep sides, and the ragstone is close to the surface. No water however flows in this channel, and it has all the characters of a chalk-wold. Its course is nearly parallel to the Medway.

The first of these lateral valleys begins in a meadow near Langley Heath, where a slight and gradual depression of the surface indicates the beginning of a great crack or fissure at right angles to the Medway valley. This gradually deepens until near Langley Church, where a small spring breaks out and runs on close to Boughton quarries, before reaching which however a fissure receives the water, and the stream is lost to view for some distance; but, as several issues of water flow out below in the same valley, there is little doubt that they come from the original source. Continuing onwards, they rum into the Medway at Tovil. The fall is very considerable, as in the distance of two and a half miles ten mills are supplied with power.*

* This is a very valuable hint for roughly obtaining the level of a district.-Ep. GEOL. 
The course of the second valley is nearly parallel with the first; the spring-head is a short distance from Chislet Park. Several smaller streams, having their origin in the Lower Chalk, fall into this valley after running over the gault and passing through cbannels formed by divisions or cracks in the ragstone beds. At Maidstone the stream mingles with the Medway.

These two cracks or valleys in the ragstone are situated on the east side of the Medway; the west has no such breakage of the strata into vales, but by its compactness turns the course of the river from south-east to north-west, which latter direction it takes on passing the town of Maidstone.

The land is of considerable elevation on the west bank of the river, and the ragstone is found in larger beds; in some situations very near the surface.

As a general rule it may be laid down that, in this district, the faults run parallel with the larger crack or valley, as is the case in all the quarries in the vicinity of Maidstone. 'The dipping of the strata is not always greatest according to the proximity to the line of disturbance; and but little variation is found from the horizontal position in the higher and more compact beds, although the abundance of vertical cracks and fissures testify to the great disturbances they have been subjected to at different periods of time.

The Kentish Ragstone series consists of limestones, with alternating beds of soft sandstone, called "Hassock" by the workmen. In some parts beds of dark flint or chert are substituted for the limestone. The average thickness of the layers is about 12 inches, and the stone is of various degrees of hardness and compactness, the lowest being the most fossiliferous, and having moreover characteristic distinctions from the upper in colour, texture, and fossil remains. In some layers the distinctions are difficult of detection, but these observations apply to the ragstone within five miles of Maidstone, and as far only as my own experience goes.

The analysis made for Professor Phillips's "Observations on the Kentish Ragstone" gives the following proportions:-

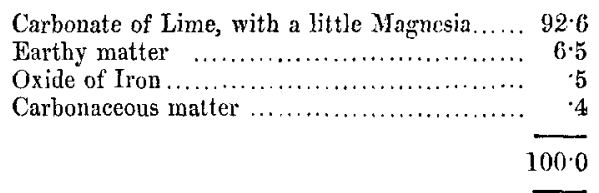

It may be interesting here to deseribe my own quarry in these much valued stone-beds, and which is known now as the "Iguanodon Quarry," from the discovery in it of the gigantic remains of that enormous reptile. It is the largest in Kent, and produces stone of very excellent quality. The number of layers of building- and roadstone is 21 , alternating with beds of hassock, and the vertical depth worked is 75 feet. The strata here have no dip, although they are traversed by numerous vertical cracks and fissures. A bed 
PLATE XVII.

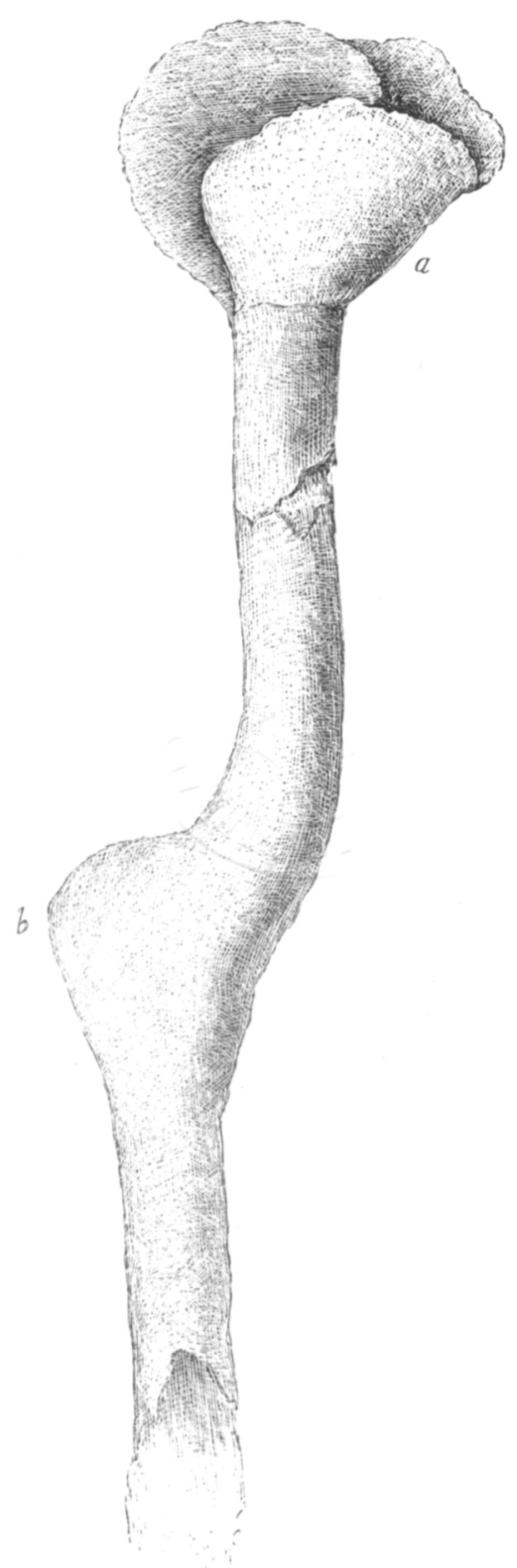

SIPHONTA BENSTEDII (Lower Greensard). [In the Collection of W. Bensted, Esq.] 
of Drift clay covers these stone-beds, and fills up the interstices of their openings, so that the land-surface shows no indication, by inequalities, of ally of these faults or fissures. The distance from the Med-

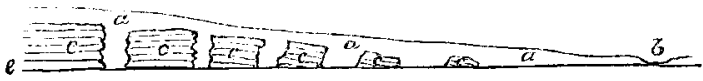

Fig. 6. a, Drift elay filling:"uy fissures in Ragstone beds, $c c ; b$, Bed of the Medway.

way is about a quarter of a mile, and the floor of the quarry is about 160 feet above the level of that river; the land gradually sloping towards it.

(To be continued.)

\section{CORRESPONDENCE.}

\section{Professor King's Synoptical Table.}

DEAR Sin,-No doubt there is much that is incorrect in my "Synoptical Table," which you have done me the honour to insert in your valuable periodical (Vol.V. pp. 193-7); but unfortunately, your correspondent "W. W.," who charges it with " many imperfections," and who fancies that he has pointed out certain of its errors in his letter, published in your last number, scems to have entirely overlooked the qualifications and spirit necessary for such a task.

The three instanees which "W. W." parades as "striking mistakes," I may be pardoned for saying are nothing of the kind, but simply intentional omissions. Any one referring to the Table itself will see that I purposely avoided, as much as possible, giving the subdivisions of the "Formations." I merely inserted what appeared to mo to be the most characteristic " Types" of the different Formations, "Marine," or " Freshwater;" believing that such were sufficient for students in general.

I shall be most happy to avail myself of any suggestions or corrections offered through the medium of your pages; but I regret I cannot adopt the Eocene classification, given by "W. W." As will presently be seen, "it is not as useful as might be to a student in the south-east of England ;" nor is it in accordance with the views of one of the highest authorities in Tertiary Geology.

The classification of the Eocene "Formation," as given in my Table, is fully borne out by the following remarks, extracted from the new edition of Jukes's admirable Manual :- "Sir C. Lyell, however, in his Supplement, thinks that it would be more convenient to retain a nomenclature common on the Continent, and to class the Hempstead series, and its contemporaneous beds as Lower Miocene, making the beds from the Barton Clay to the Bembridge series inclusive Upper Eocene, and taking the Bracklesham and Lower Bagshot beds only as Middle Eocene "-(pp. 651-2). Further, the latest investigations, such as may "be said to be up to the present time," are all strongly confirmatory of the view maintained by many geologists, that the Hempstead beds are of the "Lower Miocene" age, and not Eocene.-(See Abstract of Heer's paper, and of another by Sandberger, in the same number of the "Geologist" containing the letter of "W.W."!) I entertain a strong suspicion that even the Bembridge Marls, etc., are Miocene. 